\title{
ANALISIS SIMBOL WACANA IKLAN DETERGEN PADA SIARAN TELEVISI RCTI: KAJIAN SEMIOTIKA
}

\author{
Hetilaniar \\ heti_laniar@yahoo.co.id \\ Prodi Pendidikan Bahasa dan Sastra Indonesia \\ Fakultas Keguruan dan Ilmu Pendidikan \\ Universitas PGRI Palembang, Indonesia
}

\begin{abstract}
Abstrak
Wacana adalah sarana komunikasi yang baik dalam masyarakat. Iklan merupakan salah satu bentuk wacana yang paling mudah untuk mempengaruhi penonton. Di samping itu, iklan televisi merupakan salah satu sarana komunikasi budaya yang paling dekat dengan manusia sehingga dengan media televisi tersebut, penonton dengan mudah terpengaruh untuk melakukan budaya konsumtif. Masalah yang akan dibahas dalam penelitian ini adalah bagaimanakah makna simbol wacana iklan detergen pada siaran televisi RCTI. Diharapkan dengan adanya penelitian ini penonton lebih selektif dalam menyikapi sesuatu yang ditawarkan pada iklan televisi. Penelitian ini menggunakan teori semiotika Roland Barthes. Metode yang digunakan dalam penelitian ini adalah metode deskriptif. Data dalam penelitian ini adalah iklan detergen yang disiarkan pada stasiun televisi RCTI. Data dikumpulkan dengan menggunakan teknik rekam. Analisis data diawali dengan memotong iklan per shot, lalu memaknainya dengan menggunakan teori Roland Barthes, yaitu memaknai simbol-simbol pada iklan detergen tersebut yang dihubungkan dengan mitos. Setelah dilakukan analisis, didapat bahwa semua simbol pada iklan detergen menyiratkan kemudahan dalam melakukan kegiatan mencuci, hasil cucian akan lebih cepat bersih, detergen yang ramah lingkungan, kemandirian, baju putih tidak masalah terhadap noda membandel, dan pentingnya kedekatan ibu dan anak.
\end{abstract}

Kata Kunci: Wacana, Semiotika, Iklan Detergen

\section{Abstract}

Discourse is a media to communicated in society. Advertisment is one of discourse that can easier to influence the viewer. Thus, the advertisment in television is one of means of cultural communication that closest with human so that by television media, the viewer easier to be effected to do consumptive cultural. The problem in this paper is how the meaning of symbols in detergent advertisment in RCTI television programme. The purpose of this study is the viewer could be selective to adressing something that offered by television advertisement. This study used Rolan Barthes semiotic theory. The methodologi in this study is descriptive method. The data taken by detergent advertisment that aired in RCTI television programme. The data collected by recording method. Data analysis began by cutting the advertisment on every shot, and then interpret its by using Rolan Barthes theory, namely interpret the symbols in detergent advertisment that associated with myth. After the analysis, known id all of the symbols in detergent advertisment implies the easier way for washing, clean and faster to wash, impromentally friendly detergent, autonomy, the white shirt is not effect by dirt, and the important of mother and child relationship.

Key Words: Discourse, Semiotic, Detergent Advertisment

\section{PENDAHULUAN}

Komunikasi merupakan proses dalam menyampaikan pesan berupa gagasan, ide, atau pesan yang akan disampaikan kepada orang lain. Komunikasi dalam masyarakat akan terjalin dengan sempurna, jika terdapat kesepahaman yang sama terhadap bahasa yang digunakan. Pada umumnya dalam berkomunikasi manusia menggunakan bahasa verbal maupun nonverbal. Hal ini didukung oleh pendapat Darma (2009: 9) bahwa komunikasi dapat dilakukan dengan 
menggunakan bahasa verbal dan nonverbal.

Komunikasi dapat dilaksanakan secara lisan dan tulisan. Salah satu sarana komunikasi adalah wacana. Wacana yang disampaikan melalui media akan berbeda dengan wacana fiksi atau nonfiksi yang biasa dibaca dalam buku bacaan, yaitu penggunaan simbol-simbol dalam pelaksanaan komunikasi berkaitan erat dengan penafsiran seseorang dengan peristiwa yang terjadi di masyarakat (Darma, 2009: 10).

Pendapat Darma tersebut di atas, menguatkan pendapat bahwa setiap komunikasi baik lisan, maupun tulisan memiliki simbol yang bermakna. Dalam penyampaian pesan melalui simbol-simbol tersebut, berbagai sarana digunakan dalam berkomunikasi. Salah satu sarana komunikasi yang paling dekat dengan manusia adalah siaran televisi. Berbagai siaran yang disajikan dalam berbagai bentuk, seperti: iklan, sinetron, berita, reality show, kuis, dan sebagainya dapat mengubah gaya hidup penikmat siaran televisi, dalam hal ini penonton. Hal ini seiring dengan pendapat Bungin (2011: 132) bahwa ada semacam pembenaran masyarakat terhadap pilihan televisi sebagai medium iklan, karena banyak argumentasi di masyarakat bahwa media televisi paling kuat mempengaruhi orang lain.

Banyak stasiun televisi swasta di Indonesia, seperti: RCTI, SCTV, ANTV, Indosiar, Trans 7, dan

sebagainya. Penelitian ini Vol. 2 No. 2 April 2019

\section{4 | Jurnal Kredo}

menggunakan stasiun televisi RCTI sebagai sumber data. Putra (2012: 18), menceritakan sejarah Rajawali Citra Televisi (RCTI). RCTI adalah stasiun televisi swasta pertama di Indonesia. RCTI pertama mengudara pada 13 November 1988 dan diresmikan 24 Agustus 1989. Pada waktu itu, siaran RCTI hanya dapat ditangkap oleh pelanggan yang memiliki dekoder dan membayar iuran setiap bulannya. RCTI melepas dekodernya pada akhir 1989. Pemerintah mengizinkan RCTI melakukan siaran bebas secara nasional sejak tahun 1990 tapi baru terwujud pada akhir 1991 setelah membuat RCTI Bandung pada 1 Mei 1991. Pada 2004 RCTI termasuk stasiun televisi yang besar di Indonesia. Sejak Maret 2004, RCTI dimiliki oleh Media Nusantara Citra, kelompok perusahaan media yang juga memiliki Global TV dan TPI.

Berbagai siaran yang ditawarkan pada siaran televisi, termasuk iklan. Iklan televisi merupakan iklan yang paling enak ditonton karena pesan-pesan yang disampaikan dalam iklan televisi menyerupai film. Banyak perusahaan memilih televisi sebagai media promosi berbagai produk yang ditawarkan. Strategi iklan adalah pesan yang terlihat, karena dapat dirujuk secara jelas dalam teks pemakaian kata-kata, gambar, dan warna. Sementara dalam pesan yang tersembunyi, peneliti menggunakan interpretasi dalam menilai iklan (Eriyanto, 2011: 28). Iklan televisi merupakan sarana representasi yang

menarik untuk diteliti dan digali 
maknanya. Oleh karena itu, iklan televisi memiliki kekuatan untuk mempengaruhi penonton agar melakukan tindakan konsumtif.

Berbagai iklan yang dapat ditonton melalui televisi, seperti iklan sabun mandi, pasta gigi, detergen, shampo, dan berbagi produk rumah tangga lainnya. Produk-produk yang ditawarkan dalam iklan televisi tentunya memiliki kekuatan dalam menghadapi saingan dalam merebut perhatian pemirsa yang menonton. Hal ini didukung oleh pendapat Widyatama (2011: 42) bahwa di tengah masyarakat, disadari atau tidak iklan selalu berlomba untuk memenangkan persaingan. Tidak saja merebut persaingan dengan sesama iklan produk sejenis, melainkan juga dengan iklan-iklan berbagai produk lain.

Tidak bisa dipungkiri jika kekuatan media telah menginspirasi kajian kritik beberapa disiplin ilmu, seperti linguistik, semiotik, pragmatik, dan kajian wacana (Dijk dalam Schiffrin dkk., 2003: 359). Dengan demikian, analisis wacana pada media dapat dilihat sebagai cabang ilmu khusus kajian komunikasi massa dalam mengungkapkan sesuatu yang masih bias, sehingga maknanya dan simbolsimbol didalamnya menjadi lebih jelas dalam sudut pandang bahasa.

Iklan merupakan proses komunikasi dan gejala semiotika, yang berfungsi sebagai alat pemasaran dan sekaligus pembentukan citra pada iklan tersebut. Jika dilihat dari sudut semiotika, bisa dikaji dari sistem tanda yang terdapat dalam lambang, baik yang berupa verbal, maupun yang berupa ikon. Iklan juga merupakan tiruan indeks, terutama dalam iklan radio, televisi, dan film. Untuk itu, dalam menganalisis iklan detergen ini peneliti menggunakan teori Roland Barthes, yaitu mengungkap pesan Iklan melalui tahap denotasi dan tahap konotasi (Barthes, 2007: 282).

Dari berbagai iklan televisi yang dapat ditonton, tentunya semua dapat dijadikan sebagai objek penelitian. Pada tesis ini, peneliti membatasi hanya pada batas makna teks iklan tersebut. iklan yang dipilih sebagai objek penelitian adalah iklan detergen. Detergen merupakan salah satu kebutuhan pokok rumah tangga yang paling dekat dengan kaum hawa. Dengan adanya detergen, ibu rumah tangga lebih mudah untuk membersihkan pakaian yang dikenakan sehari-hari. iklan detergen memiliki pengaruh dalam mengubah gaya hidup penikmat iklan, terutama kaum ibu rumah tangga. Berbagai merek detergen ditawarkan di televisi, seperti Rinso, Attack, DAIA, BOOM, Surf, dan sebagainya.

Dalam penelitian ini, dipilih merek detergen yang muncul pada siaran televisi RCTI saja karena setelah dilakukan observasi, ternyata tidak semua iklan detergen dengan merek yang sama muncul pada seluruh stasiun televisi. iklan detergen yang sering muncul pada siaran televisi 
RCTI adalah Rinso Antinoda, Surf, DAIA, Rinso Cair Antinoda dan Attack. Dipilihnya stasiun televisi RCTI sebagai sumber penelitian dikarenakan stasiun pertama kali di Indonesia adalah $R C T I$ dan Iklan detergen paling banyak disiarkan pada stasiun televisi RCTI.

Penelitian tentang representasi gaya hidup Iklan televisi, pernah diteliti oleh Riza Syahrela, dengan judul tesisnya "Representasi Gaya Hidup dalam Iklan Televisi (Analisis Wacana: Iklan Kosmetik di Televisi)", Universitas Indonesia, Fakultas Ilmu Sosial dan Ilmu Politik, Departemen Ilmu Komunikasi, tahun 2006. Perbedaan dengan penelitian pada tesis ini terletak pada objek penelitian. Pada penelitian Riza Syahrela, objek penelitiannya adalah iklan kosmetik, yaitu Citra Lotion, Ponds Facial Foam, dan Olay Lotion, sedangkan objek penelitian ini adalah iklan detergen pada siaran televisi RCTI. Selain itu, pada penelitian ini, hanya menganalisis simbol-simbol yang terdapat dalam iklan detergen dengan menggunakan teori Roland Barthes.

Berdasarkan pernyataan di atas, mendeskripsikan dan mengetahui makna simbol wacana iklan detergen pada siaran televisi RCTI dengan menggunakan kajian semiotika Roland Barthes dijadikan tujuan yang akan dicapai dalam penelitian ini. Permasalahan yang akan dibahas dalam penelitian ini adalah "Bagaimanakah makna simbol yang tersirat dan tersurat pada simbolsimbol wacana iklan detergen pada siaran televisi RCTI dengan

\section{6 | Jurnal Kredo} Vol. 2 No. 2 April 2019 menggunakan teori semiotika Roland Barthes?".

\section{KAJIAN TEORI}

Komunikasi yang terjadi pada manusia akan dapat berjalan dengan lancar jika terdapat alat komunikasi yang saling pengertian. Alat komunikasi yang dimaksud adalah kata atau bahasa. Kata atau bahasa yang terdapat dalam wacana linguistik, diberi pengertian sebagai sistem bunyi yang memiliki simbol bermakna dan artikulasi yang tepat (dihasilkan oleh alat ucap), yang bersifat berubah-ubah (arbitrer), dan konvensional, yang dipakai sebagai alat komunikasi sekelompok manusia untuk melahirkan perasaan dan pikiran (Sobur, 2009: 42).

$$
\text { Simbol juga digunakan }
$$

dalam istilah satra. Menurut Pradopo (1995:120) mengatakan bahwa simbol merupakan tanda yang ditunjukkan tidak ada hubungan alamiah antara penanda dan petandanya, hubungannya bersifat arbitrer (semau-maunya). Artinya, tanda itu ditentukan oleh konvensi. 'Ayah' disebut simbol, Masyarakat bahasa menentukan makna dari sebuah bahasa. Orang Inggris menyebutnya Mother, Francis menyebutnya la mere, dan sebagainya. Dengan demikian, adanya macam-macam tanda untuk satu arti itu menunjukkan "kesemena-menaan" tersebut sehingga dapat dikatakan bahwa tanda yang bayak digunakan dalam bahasa adalah simbol. 
Kesatuan bahasa yang lengkap adalah wacana, bukan kata atau kalimat. Wacana menurut Dijk (dikutip Lubis, 2011: 23) sama dengan teks, yaitu kesatuan dari beberapa kalimat yang satu dengan yang lain terikat dengan erat. Seiring dengan pendapat di atas, Kridalaksana (2009: 259) mengungkapkan bahwa satuan bahasa terlengkap yang juga satuan gramatikal tertinggi dan terbesar desebut wacana. Pendapat serupa diungkapkan oleh Chaer (2007: 267) bahwa wacana adalah satuan gramatikal tertinggi atau terbesar secara hierarki gramatikal dan satuan bahasa yang lengkap.

Berdasarkan pendapat di atas, wacana merupakan kesatuan kalimat yang lengkap dengan satuansatuan yang saling berkesinambungan. Satuan-satuan yang dimaksud adalah kohesi dan koherensi, karena sebenarnya salah satu ciri wacana yang baik adalah kohesi dan koherensi. Kohesi atau kepaduan terdapat dalam kesatuan wacana. Namun, kesatuan dapat diciptakan oleh pengarang atau pembaca dalam memahami isi wacana. Hal ini didukung oleh pendapat Tarigan (2009: 66) bahwa seperangkat proposisi yang paling berhubungan untuk menghasilkan rasa kepaduan atau rasa kohesi disebut wacana yang ideal. Selain itu, dibutuhkan juga keteraturan atau kerapian susunan yang menimbulkan rasa koherensi.

Iklan identik dengan sarana pemasaran produk yang promosikan melalui media cetak, maupun elektronik. Iklan berusaha untuk mempengaruhi perhatian, menciptakan hasrat, dan pada akhirnya akan menggerakkan penonton untuk tertarik membeli produk yang ditawarkan dalam iklan. iklan biasanya bersifat persuasif karena sebenarnya iklan dapat juga disebut dengan pesan bisnis. Bovee dan Thill (2007: 403) mengungkapkan bahwa sejumlah besar pesan bisnis persuasif akan melibatkan permohonan untuk melakukan tindakan. Hampir semua pesan persuasif internal terfokus pada bagaimana membuat audiens mau membuat keputusan atau mengambil tindakan spesifik.

Pengertian iklan jika dilihat dari sudut pandang pemasaran dipandang sebagai alat untuk memasarkan produk yang dipasarkan, dalam perspektif semiologi, iklan disebut sebagai seperangkat tanda yang berfungsi menyampaikan sejumlah pesan (Kasiyan dikutip Widyatama, 2011: 27). Dengan demikian, untuk memahami simbolsimbol yang ada dalam iklan, dapat dianalisis dengan menggunakan teori semiotika. Simbol adalah label arbitrer atau representasi dari fenomena (Rohim, 2009: 13). Kata dalam iklan adalah simbol untuk konsep atau benda, misalnya kata Rinso merepresentasikan merek salah satu detergen yang dapat membersihkan noda pada baju.

$$
\text { Pemikiran }
$$

Saussure

diteruskan oleh Roland Barthes yang ditekankan pada interaksi antara teks dengan pengalaman 
personal dan kultural penggunanya, interaksi antara konvensi dalam teks dengan konvensi yang dialami dan diharapkan oleh penggunanya. Gagasan Barthes ini dikenal dengan "order of signification", yaitu makna denotasi yang merupakan makna sebenarnya, dan makna konotasi makna yang memiliki makna ganda sesuai dengan kultur sosial dalam masyarakat. Inilah yang membedakan Saussure dan Barthes. Namun demikian istilah signifier-signified tetap digunakan Barthes yang dikenalkan Saussure.

Pada semiotik Roland Barthes terdapat dua tahap yang akan dianalisis. Tahap pertama disebut dengan tahap denotatif, yaitu tahap analisis dipandang dari segi kebahasaan. Makna denotatif yaitu makna yang sebenarnya. Artinya, pada tahap denotatif ini merupakan tahap pemaknaan yang paling nyata. Tahap kedua pada teori Barthes adalah tahap konotatif, yaitu tahap pemaknaan yang berkenaan dengan mitologi. Hal inilah yang membuat teori Barthes berbeda dengan teori Saussure. Pada teori Saussure hanya berhenti pada tahap linguistik, atau pada teori Barthes disebut dengan tahap pertama.

Teori semiotik Barthes hampir secara harfiah diturunkan dari teori bahasa menurut Saussure. Sebagaimana pandangan Saussure, Barthes juga meyakini bahwa hubungan antara penanda dan pertanda tidak terbentuk secara alamiah, melainkan bersifat arbitrer.
Peta tanda Roland Barthes dapat digambarkan sebagai berikut.

\begin{tabular}{|c|c|c|}
\hline $\begin{array}{l}\text { 1.Signifi } \\
\text { er } \\
\text { (Penand } \\
\text { a) }\end{array}$ & $\begin{array}{l}\text { 2.Signifie } \\
\quad d \\
\text { (pertanda } \\
\text { ) }\end{array}$ & \\
\hline \multicolumn{3}{|c|}{$\begin{array}{l}\text { 3. Denotative sign } \\
\text { (tanda denotative) }\end{array}$} \\
\hline \multicolumn{2}{|c|}{$\begin{array}{l}\text { 4.CONNOTATIVE } \\
\text { SIGNIFIER } \\
\text { (PENANDA } \\
\text { KONOTATIF) } \\
\end{array}$} & $\begin{array}{l}\text { 5. CONNOTATIV } \\
\text { E SIGNFIED } \\
\text { (PERTANDA } \\
\text { KONOTATIF) }\end{array}$ \\
\hline \multicolumn{2}{|c|}{$\begin{array}{c}\text { 6.CONNOTATIVE } \\
\text { KONOTATIF) }\end{array}$} & SIGN (TANDA \\
\hline
\end{tabular}

Berdasarkan peta Barthes di atas pada tahap denotatif (3) terdiri atas penanda (1) dan pertanda (2). Namun, tanda denotatif merupakan penanda konotatif (4). Pada tahap konotatif (6) terdapat penanda (4) dan petanda konotatif (5). Jadi dalam konsep Barthes, tanda konotatif tidak sekedar memiliki makna tambahan, namun juga mengandung kedua bagian tanda denotatif yang melandasi keberadaannya.

\section{METODE PENELITIAN}

Penelitian ini menggunakan metode penelitian kualitatif deskriptif. Peneliti mengambil data penelitian berupa rekaman iklan di siaran televisi RCTI dengan menggunakan teknik rekam dan dokumentasi. Teknik analisis data dalam penelitian ini adalah teknik analisis isi. Teknik analisis isi adalah 
suatu teknik penelitian yang dilakukan secara objektif, sistematis dan deskripsi dari isi komunikasi yang tampak (manifest).

\section{HASIL DAN PEMBAHASAN}

Berdasarkan hasil analisis terhadap lima iklan detergen, yaitu: Rinso Anti Noda, Attack Easy, Surf, Daia, dan Rinso Cair Anti Noda, diketahui jika masing-masing detergen berupaya untuk menarik dan meyakinkan konsumennya dengan melakukan beberapa diksi dan simbol-simbol yang dapat mempengaruhi orang yang melihatnya. Beberapa hasil analisis yang dilakukan terhadap kelima iklan detergen tersebut dapat dilihat pada hasil analisis berikut ini.

\section{Makna Simbol Wacana Iklan Detergen Rinso Anti Noda}

Setelah dilakukan analisis, makna simbol yang terdapat dalam wacana iklan detergen Rinso Anti Noda, yaitu simbol warna yang terdapat pada iklan tersebut tersirat makna bahwa Rinso Anti Noda merupakan detergen yang ramah lingkungan dan digunakan oleh semua lapisan masyarakat, dari kalangan bawah hingga kalangan atas, hal ini dapat dilihat dari beberapa simbol yang dimunculkan, salah satunya adalah terdapat simbol mobil dan rumah permanen yang menyimbolkan status sosial pemiliknya. Sebuah mobil dan rumah permanen cukup mewakili kondisi ekonomi pemiliknya yang berasal dari kalangan dengan ekonomi yang mapan.

Segala kegiatan yang dilakukan sendiri seperti: mencuci, mengecat, dan memasak menyimbolkan kemandirian; dalam salah satu shot terdapat tokoh ayah, ibu, dan satu anak menyimbolkan keluarga kecil yang bahagia; latar musik 'Di Sini Senang Di Sana Senang' menyimbolkan suasana hati ibu dan anak yang bahagia dalam melakukan segala pekerjaan di rumah; dan diakhiri dengan kalimat "Berani kotor itu baik" menyiratkan makna bahwa sesuatu yang kotor tidak selalu membawa pengaruh jelek, melainkan terdapat pengalaman yang berharga.

Berdasarkan beberapa potongan analisis shot di atas dapat diketahui jika Rinso Anti Noda adalah detergen yang digunakan oleh semua kalangan, baik kalangan bawah, hingga kalangan atas. Mencuci dengan menggunakan Rinso Anti Noda membuat kegiatan mencuci menjadi lebih menyenangkan, pesan lain yang ingin disampaikan adalah noda pada pakaian bukan lagi halangan bagi semua anggota keluarga untuk beraktivitas karena dengan Rinso Anti Noda semua noda membandel dapat dihilangkan dengan mudah.

\section{Makna Simbol Wacana Iklan Detergen Attack Easy}

Hasil analisis terdapat makna simbol wacana iklan detergen Attack Easy juga menyiratkan beberapa simbol yang dapat dimaknai, seperti 
latar musik ceria dengan tampilan kemasan Attack Easy menyiratkan makna bahwa kegiatan mencuci dengan menggunakan detergen Attack Easy merupakan kegiatan yang menyenangkan; banyaknya tokoh ibu dengan berbagai etnik menyiratkan makna Attack Easy dipakai oleh semua kaum ibu; kekuatan sepuluh tangan menyiratkan makna Attack Easy memiliki kekuatan yang lebih untuk membersihkan pakaian; dan simbol burung perkutut pada iklan tersebut menyiratkan makna status sosial tokoh iklan termasuk kalangan priyayi; warna hijau pada kemasan menyiratkan makna eksplorasi alam, artinya detergen Attack Easy ramah lingkungan.

Berdasarkan hasil analisis terhadap beberapa shot yang telah dilakukan tersebut dapat diketahui jika detergen Attack Easy adalah detergen yang juga menjadi pilihan para ibu. Dengan banyaknya para ibu yang menggunakan detergen ini mengindikasikan jika mutu Attack Easy dapat dipercaya dalam membesihkan pakaian yang terkena noda. Dengan kekuatan dan daya cuci yang sama dengan kekuatan sepuluh tangan menjadikan hasil cucian menjadi sepuluh kali lebih bersih dibandingkan dengan detergen biasa. Hal ini juga menyiratkan makna jika Attack Easy menjadikan kegiatan mencuci menjadi lebih mudah dan menyenangkan.

Sedangkan untuk kalangan yang menggunakannya dapat dilihat dari beberapa tokoh ibu dan latar

320 | Jurnal Kredo Vol. 2 No. 2 April 2019 rumah yang mereka miliki. Dalam salah satu shot diperlihatkan jika dipekarangan belakang rumah salah satu ibu yang tengah mencuci ada gantungan burung perkutut. Dalam tradisi masyarakat Jawa, orang-orang yang memelihara burung perkutut adalah kalangan menengah ke atas dan golongan priyayi. Dengan demikian dapat dinyatakan jika Attack Easy juga digunakan oleh kalangan menengah ke atas.

Selain keampuhannya dalam mencuci, Attack Easy juga menyimbolkan

keramahlingkungannya detergen tersebut. Dengan kemasan berwarna hijau pada kemasan yang menyimbolkan sifat yang ramah lingkungan.

\section{Makna Simbol Wacana Iklan Detergen Surf}

Setelah dilakukan analisis, terdapat makna simbol wacana iklan detergen Surf, yaitu tokoh tiga orang ibu dengan membawa keranjang menyiratkan makna ketiga ibu telah melakukan kegiatan belanja di pasar tradisional; latar gedung sekolah yang berdiri megah menyiratkan makna bahwa sekolah itu penting; baju putih yang berkilau menyiratkan makna mencuci menggunakan detergen Surf, pakaian putih akan lebih berkilau; gambar petir pada kemasan menyiratkan makna kecepatan detergen dalam bekerja membersihkan noda/warna kekuningan; logo Unilever pada kemasan menyimbolkan berbagai 
jenis produk yang dikeluarkan oleh PT Unilever.

Dari potongan-potongan shot yang ada dapat disimpulkan jika detergen Surf adalah detergen yang banyak digunakan oleh para ibu. Surf merupakan detergen pencuci yang digunakan oleh berbagai kalangan, jika dilihat dari potongan shot yang ada, walaupun para ibu dalam iklan tersebut bergaya sederhana, namun mereka berasal dari kalangan menengah, hal ini dapat diliat dari sekolah anak-anak mereka yang cukup megah. Hal ini sudah cukup mewakili jika mereka berasal dari kalangan ekonomi menengah ke atas.

Desain kemasan detergen juga dirancang dengan aksen simbolsimbol yang sangat kuat, seperti gambar kilatan petir pada kemasan yang menyiratkan kekuatan dan kecepatan detergen Surf dalam membersihkan noda. Dengan keampuhan yang sedemikian dahsyatnya tersebut, semua jenis noda akan dapat dengan mudah dihilangkan.

\section{Makna Simbol Wacana Iklan Detergen DAIA}

Setelah dilakukan analisis, didapat makna simbol wacana iklan detergen DAIA, yaitu bunga lili putih menyiratkan makna kemurnian; rumah yang megah menyiratkan kelas sosial tokoh (kalangan atas); gaun putih yang dikenakan tokoh ibu menyiratkan makna bahwa pakaian putih akan lebih mudah mengikat kotoran; coklat yang menempel pada gaun tokoh ibu menyiratkan makna noda yang paling sulit dibersihkan lebih mudah dibersihkan dengan menggunakan detergen DAIA; ketakutan anak bahwa ibunya tidak mau dipeluk karena ia memakai baju putih menyiratkan makna sebelum ibu menggunakan detergen DAIA, tokoh ibu tidak mau dipeluk oleh anaknya jika ia memakai baju putih.

Berdasarkan hasil analisis per shot dapat disimpulkan jika detergen Daia ini diperankan oleh ibu yang berasal dari kalangan menengah ke atas. Kegemarannya merangkai bunga lili segar di rumah, suasana dan kondisi rumah yang sangat nyaman dan bersih, serta pakaian yang digunakannya cukup memberikan gambaran jika dia berasal dari kalangan menengah ke atas. Gambaran tersebut juga dapat dimaknakan jika detergen Daia tidak hanya digunakan oleh kaum menengah ke bawah saja, namun juga menjadi pilihan ibu-ibu dari kalangan atas. Hal ini juga mengindikasikan jika kualitas yang dimiliki oleh detergen Daia sudah teruji dan dipercaya oleh semua kalangan.

Pada shot lainnya diperlihatkan seorang anak yang tengah membawa donat. Pakaian yang digunakan si anak penuh dengan noda coklat, dia tidak berani untuk memeluk ibunya yang tengah menggunakan baju berwarna putih karena takut akan mengotori baju ibunya. Namun, ketika sang ibu melihat anaknya itu, dia tanpa raguragu memeluk si anak. Dia sama sekali tidak khawatir dengan noda 
yang akan menempel dipakaiannya. Hal ini menyiratkan makna jika si ibu tidak perlu merasa khawatir dengan semua noda yang menempel dipakaian mereka, karena semua noda tersebut akan dapat dibersihkan dengan mudah dengan menggunakan detergen Daia.

\section{Makna Simbol Wacana Iklan Detergen Rinso Cair Anti Noda}

Setelah dilakukan analisis, didapat makna pada simbol wacana iklan detergen Rinso Cair Anti Noda, yaitu tokoh dua anak yang kembar dan sekolah di tempat yang sama; anak-anak selalu bertindak spontan tanpa diduga sebelumnya; anak kecil yang sangat rentan dengan kebosanan dan memiliki tingkat mobilitas dan aktivitas yang sangat tinggi; sang kakak bertanggung jawab dalam melindungi adiknya; rasa percaya diri yang tinggi atas usaha yang dilakukan saudaranya; sikap menyerah dan pasrah pada keadaan yang telah terjadi; hubungan yang sangat akrab yang dipercaya dapat memberikan efek positif secara psikologis; gaya hidup seorang ibu rumah tangga yang modern dan modis; dan daya cuci rinso cair sangat ampuh sehingga tidak dibutuhkan jumlah yang banyak untuk membersihkan noda.

Hasil analisis per shot yang dilakukan pada iklan detergen Rinso Cair juga menggambarkan di atas menggambarkan jika detergen Rinso Cair kembali mendapat kepercayaan dari semua kalangan. Tempat sekolah kedua anak kembar dan rumah yang mereka tempati menggambarkan jika mereka berasal dari kalangan 'berada'. Hal ini menegaskan jika, Rinso Cair juga dipercaya oleh banyak kalangan, tidak hanya kalangan bawah saja.

Pada salah satu shot ditampilkan jika si ibu mencuci pakaian ditempat yang sangat rapi dan tetap dengan menggunakan pakaiannya yang modis. Hal ini menggambarkan betapa mudahnya kegiatan mencuci tersebut bagi si ibu. Dia diberikan banyak kemudahan dan kenyamanan saat mencuci pakaian sehingga dia tidak merasa perlu untuk mengganti pakaiannya.

Shot lainnya menggambarkan jika si ibu hanya membutuhkan satu tutup takar untuk mencuci pakaian tersebut. Hal ini menggambarkan betapa mudah dan hematnya Rinso Cair dalam penggunaannya. Tidak dibutuhkan banyak detergen untuk menghilangkan noda. Hal ini menyiratkan arti jika Rinso Cair adalah detergen pembersih yang sempurna.

\section{SIMPULAN}

Berdasarkan hasil analisis yang telah dilakukan pada kelima detergen pencuci di atas. Dapat ditarik beberapa simpulan, diantaranya adalah: (1) kelima detergen pencuci pakaian tersebut semuanya menawarkan kemudahan dan menonjolkan kualitas produk masing-masing. Kemudahan dan keampuhan daya cuci masing-masing 
detergen disimbolkan dengan berbagai cara seperti kekuatan sepuluh tangan, takaran yang sedikit, kecepatan seperti petir, kilauan pada pakaian, dan sebagainya, (2) Kelima detergen pencuci pakaian tersebut diwakili oleh kalangan-kalangan menengah ke atas, hal ini dapat dilihat dari kondisi rumah dan ibuibu yang memerankannya. Semuanya rumah dalam kondisi yang sangat baik dan memiliki fasilitas yang sangat lengkap, dan para ibu mencuci dengan menggunakan pakaian dan dandanan yang modis khas ibu-ibu muda. Hal ini menggambarkan jika detergen pencuci ini menjadi pilihan semua kalangan.

Berdasarkan hasil penelitian di atas, beberapa hal yang dapat disarankan oleh peneliti adalah (1) penonton diharapkan dapat lebih selektif dalam menerima segala bentuk informasi dan tayangan iklan yang ada. Karena, dari kelima detergen pencuci tersebut, semuanya memiliki tanda bintang (*) yang artinya syarat dan ketentuan berlaku. Tanda bintang dan kalimat ini dibuat lebih kecil ukurannya dan letaknya agak 'tersembunyi' pada kemasan. Hal ini merupakan trik produsen untuk menghindar dari kalimat 'penipuan' jika ada konsumen yang komplain terhadap detergen yang mereka jual, karena jika menginginkan hasil cucian yang sesuai dengan apa yang mereka iklankan maka harus menuruti syarat dan ketentuan tersebut, (2) penelitian ini juga masih memiliki banyak kekurangan, oleh karena itu hendaknya peneliti lainnya dapat melakukan penelitian-penelitian lainnya dengan menggunakan objek kajian yang berbeda dan tidak hanya terfokus pada satu siaran televisi saja.

\section{DAFTAR PUSTAKA}

Barthes, Roland. 2007. Petualangan Semiologi. Terjemahan Stephanus Aswar Herwinarko. Yogyakarta: Pustaka Pelajar.

Bovee, Courtland L. dan John V. Thill. 2007. Komunikasi Bisnis. Jakarta: PT Indeks.

Bungin, Burhan. 2011. Konstruksi Sosial Media Massa. Jakarta: Kencana Prenada Media Group.

Chaer, Abdul. 2007. Linguistik Umum. Jakarta: Rineka Cipta.

Darma, Yoce Aliah. 2009. Analisis Wacana Kritis. Bandung: Yrama Widya. 
Eriyanto. 2011. Analisis Isi: Pengantar Metodologi untuk Penelitian llmu Komunikasi dan llmu-ilmu Lainnya. Jakarta: Kencana Prenada Media Group.

Eriyanto. 2011. Analisis Wacana Pengantar Analisis Teks Media. Yogyakarta: LkiS Printing Cemerlang.

Kridalaksana, Harimurti. 2009. Kamus Linguistik. Jakarta: PT Gramedia Pustaka Utama.

Lubis, Hamid Hasan. 2011. Analisis Wacana Pragmatik. Bandung: Angkasa.

Putra, Dedi Kurnia Syah. 2012. Media dan Politik. Yogyakarta: Graha Ilmu.

Pradopo, Rachmat Djoko. 1995. Beberapa Teori Sastra, Metode, dan Penggunaannya. Yogyakarta: Pustaka Pelajar.

Rohim, Syaiful. 2009. Teori Komunikasi Perspektif, Ragam, dan Aplikasi. Jakarta: Rineka Cipta.

Sobur, Alex. 2009. Analisis Teks Media. Bandung: PT Remaja Rosdakarya.

Sobur, Alex. 2009. Semiotika Komunikasi. Bandung: PT Remaja Rosdakarya.

Syahrila, Riza. 2006. Representasi Gaya Hidup dalam Iklan Televisi (Analisis Wacana: Iklan Kosmetik di Televisi). Tesis. Jakarta: Universitas Indonesia.

Tarigan, Henry Guntur. 2009. Pengajaran Wacana. Bandung: Angkasa

Widyatama, Rendra. 2011. Teknik Menulis Naskah Iklan. Jakarta. Cakrawala. 